\title{
SISTEM BIKAMERAL DI LEMBAGA LEGISLATIF BERDASARKAN TUGAS \\ DAN KEWENANGAN DEWAN PERWAKILAN DAERAH \\ (Perbandingan dengan Amerika Serikat, Inggris, dan Argentina)
}

Oleh:

\author{
Yokotani, S.H., M.H.* \\ E-Mail: yokotani@ymail.com
}

\begin{abstract}
The role of the legislature as a representation of the people has been much improved. The duties and functions and forms of this institution are also developing which has the system of state government and the form of its state. The legislature as an institution must exist in the system of government and any state form applied in the countries of the world. But the development of the chamber that is applied by each country is sometimes different from each other despite having the same governmental system and state form.
\end{abstract}

Keywords :Bicamberal,Chamber.

\section{A. PENDAHULUAN}

Selama lebih dari 200 (dua ratus) tahun terakhir, lembaga legislatif merupakan institusi kunci (key institutions) dalam perkembangan politik negara-negara modern. Menilik perkembangan lembaga negara, lembaga legislatif merupakan cabang kekuasaan pertama yang mencerminkan kedaulatan rakyat.

Dalam pandangan CF. Strong, "lembaga legislatif merupakan kekuasaan pemerintahan yang mengurusi pembuatan hukum, sejauh hukum tersebut memerlukan kekuatan Undang-Undang (statutory force $) .1$

\footnotetext{
*Dosen Tetap Fakultas Hukum Universitas Bangka Belitung.

${ }^{1}$ C.F Strong, Modern Polituical Constitution An Introduction to the Comparative Study of
}

Pandangan CF.Strong kemudian dipertegas oleh Hans Kelsen, bahwa "fungsi legsilatif dipahami bukan sebagai pembentukan dari semua norma umum, malainkan hanya pembentukan norma umum yang dilakukan oleh organ khusus, yang disebut sebagai lembaga legislatif".2

Peranan lembaga legislatif sebagai representasi dari pada rakyat telah banyak mengalami perkembangan. Tugas dan fungsi serta bentuk lembaga ini pun juga berkembang yang mengiri sistem pemerintahan negara serta bentuk negaranya.

\footnotetext{
Their History and Existing Form, Sidwick \& Jackson Ltd, Londong, 1975, hlm. 8.

${ }^{2}$ Hans Kelsen, General Theory of Law and State, Russel \& Russel, New York, hlm. 256.
} 
Dewasa ini mayoritas negaranegara di dunia menerapkan sistem pemerintahan parlementer dan sistem pemerintahan presidensiil meskipun acap kali kedua sistem pemerintahan tersebut memiliki unsur-unsur satu sama lain yang sering disebut sistem pemerintahan quasi-presidensiil atau sistem pemerintahan quasiparlementer.

Lembaga legislatif sebagai lembaga yang wajib ada dalam sistem pemerintahan dan bentuk negara apapun yang diterapkan di negaranegara dunia. Namun perkembangan yang terjadi bentuk kamar (chamber) yang diterapkan tiap-tiap negara kadangkala berbeda satu sama lain meskipun memiliki sistem pemerintahan dan bentuk negara yang sama. Karakteristik bentuk kamar yang lazimnya di dunia memiliki 2 bentuk antara lain unikameral dan bikameral. Karakterisitik bentuk unikameral dalam lembaga legislatif di negara dunia, majelis legislatif terpusat pada satu badan legislatif tertinggi dalam struktur negara. Isi aturan mengenai fungsi dan tugas parlemen unikamaral ini beragam dan bervariasi dari satu negara ke negara lain, tetapi pada pokoknya serupa bahwa secara kelembagaan fungsi legislatif tertinggi diletakkan sebagai tanggung jawab satu badan tertinggi yang dipilih oleh rakyat. ${ }^{3}$

Sedangkan untuk model bentuk dua kamar atau bikameral pada hakikatnya mengidealkan adanya dua kamar di dalam lembaga perwakilan. Doktrin ini berasal dari teori klasik Aristoteles dan Polybus yang berargumentasi, bahwa pemerintahan yang baik adalah gabungan antara prinsip demokrasi dan oligarki. Namun, pandangan mengenai bikameral ini dikemukakan pertama kali oleh Jeremy Betham. Dan bentuk parlemen dua kamar inilah yang banyak digunakan oleh negara modern saat ini. ${ }^{4}$

Dalam perkembangan selanjutnya, bentuk sistem bikameral ini juga mengalami perkembangan dan memiliki keanekaragaman bentuk menurut pandangan Giovani Sartori membagi model bikameral ini menjadi tiga jenis, yaitu (1) Sistem Bikameral yang lemah (asymmetric bicameralism/weak bicameralism/soft bicameralism), yaitu apabila kekuatan salah satu kamar jauh lebih dominan

${ }^{3}$ Jimly Asshiddiqie, Pergumulan Peran Parlemen dan Parlemen dalam Sejarah; Telaah Perbandingan Konstitusi Berbagai Negara, UI Pressm Jakarta, 1996, Hlm 36.

${ }^{4}$ Saldi Isra, Pergeseran Fungsi Legislasi; menguatnya Model Legislasi Parlementer dalam SIstem Presidensial Indonesia, Rajawali Pers, Jakarta, 2010, hlm 235. 
atas kamar lainnya; (2) Sistem

Bikameral yang simetris atau relatif sama kuat (symmetric bicameralis/strong bicameralism) apabila kekuatan antara kedua kamarnya nyaris sama kuat; dan (3) perfect bicameralism, yaitu apablia kekuatan antata kedua kamar betulbetul seimbang. ${ }^{5}$

Argumentasi dari Giovani Sartori di atas cukup menggambarkan kriteria bikameral yang ada di negaranegara dunia. Masing-masing bentuk kamar pada lembaga legislatif yang diterapkan oleh negara-negara dunia terutama dengan sistem pemerintahan presidensiil tentunya tetap mempertahankan mekanisme check and balace dengan lembaga kekuasaan lainnya sebagaimana teori trias politica Montesquieu.

Di Indonesia sendiri yang notabene negara yang menerapkan sistem pemerintahan presidensiil, pasca amandemen telah melahirnkan satu kamar baru dalam lembaga legislatifnya, yang dikenal dengan Dewan Perwakilan Daerah (DPD) yang basis represntasinya adalah daerah-daerah utamanya daerah provinsi. DPD sendiri memiliki tugas

${ }^{5}$ Giovanis Sartori, Comparative Constitutional Engineering, hlm. 184 dalam Ibid., Hlm 236. dan kewenangan yang dicantumkan di dalam Konstitusi.

Awal kemunculan DPD hingga saat ini masih banyak menuai berbagai problem, utamanya berkaitan dengan tugas dan kewenangan yang dialamatkan kepadanya. Banyak dari kalangan akademisi, praktis, dan politisi menginginkan untuk pemberian kewenangan yang lebih kepada DPD ini dengan melakukan amandemen UUD 1945, namun sebelum beranjak dari aspek penambahan kuota tugas dan kewenangan DPD ini, tentunya harus kita lihat bentuk kamar apa yang diusung dalam lembaga legislatif Negara Republik Indonesia saat ini dengan kehadiran DPD. Sehingga meskipun banyak dari kalangan akademisi, praktisi, maupun politisi yang berjibaku menginginkan reformasi lembaga DPD, akan pola tugas dan kewenangan DPD harus kita uraikan secara jelas, sehingga dapat ditentukan bentuk kamar apa yang diterapkan lembaga legislatif di Negara Republik Indonesia dengan kehadiran lembaga DPD ini.

Berdasarkan uraian tersebut di atas, maka dapat dirumuskan pokok permasalahan, sebagai berikut:

1. Bagaimana bentuk dua kamar (bikamerlism) dalam struktur 
lembaga legislatif berdasarkan hubungan antar kamar?

2. Bagaimana bentuk bikameral di Negara Amerika Serikat, Inggris, dan Perancis?

3. Bagaimana bentuk bikameral di Negara Indonesia dengan kehadiran DPD?

\section{B. PEMBAHASAN}

\section{Analisis Bentuk Kamar dalam}

\section{Struktur Lembaga Legislatif}

Secara umum, dalam pembentukan UU, struktur parlemen hanya mengenal sistem unikameral atau sistem bikameral pada parlemen di berbagai negara di dunia, bahkan pada negara yang struktur parlemennya multikameral. Kewenangan kamar kedua yang subordinat terhadap kamar pertama pada berbagai negara yang dibahas bervariasi dalam kaitannya dengan pembentukan UU, yaitu: ${ }^{6}$

a. Kamar kedua memiliki kewenangan membentuk UU yang terbatas, yang tertinggi atas:

1) Kamar kedua memiliki kewenangan mengusulkan dan membahas, serta memutuskan

2) Kamar kedua memiliki kewenangan mengusulkan dan membahas, serta memutuskan

\footnotetext{
${ }^{6}$ Fatmawati, Truktur dan Fungsi Legislasi Parlemen dengan Sistem Multikameral; Studi Perbandingan Antara Indonesia dan Berbagai Negara, UI Press, Jakarta, 2010, HIm 237
}

kecuali terhadap RUU finansial.

3) Kamar kedua memiliki kewenangan mengusulkan dan membahas, serta memutuskan jika yang dibahas adalah RUU organik yang berkaitan dengan kamar kedua.

4) Kamar kedua hanya memiliki kewenangan mengusulkan RUU yang berkaitan dengan provinsi, serta memiliki kewenangan membahas dan memutuskan semua RUU

5) Kamar kedua memiliki kewenangan membahas dan memutuskan

6) Kamar kedua memiliki kewenangan mengusulkan jika bersama dengan kamar pertama dalam joint session, memiliki kewenangan membahas dan memutuskan

7) Kamar kedua memiliki kewenangan membahas dan menunda pelaksanaan RUU Non Finansial selama 1 tahun.

b. Kamar kedua tidak memiliki kewenangan membantuk RUU

Dalam hal struktur parlemen di berbagai negaratersebut dianalisis berdasarkan fungsi legislasi parlemen yang dibatasi hanya dalam hal pembentukan UU, yaitu dibahas mengenai mekanisme hubungan antarkamar dalam pembentukan RUU pada parlemen, maka dari berbagai negara tersebut diambil beberapa negara yang kedua kamarnya memiliki kewenangan membentuk RUU sedangkan pada negara lainnya hanya memiliki kamar pertama yang memiliki kewenangan membentuk UU.

Berkaitan dengan hal tersebut, berikut paparan sistem bikameral 
yang lazimnya digunakan di negaranegara di dunia :

a. Negara yang menggunakan sistem perfect bicameralism

$$
\text { Pada negara yang }
$$
menggunakan sistem perfect bicameralism, tidak ada perbedaan antar mekanisme pembentukan UU finansial dan non finansial. Kedua kamar memiliki kewenangan yang sama dalam mengusulkan, membahas dan menyetujui kedua jenis UU tersebut.

Pada negara yang dibahas, mengatur bahwa kedua kamar membahas RUU. Semua negara tersebut menggunakan navette (shuttle) system, yaitu bahwa kamar yang mengusul RUU yag memberikan pada kamar yang lain RUU tersebut di bahasdan kemudian kamar tersebut memberikan pertimbangannya tentang RUU tersebut kepada kamar yang mengusulkan. ${ }^{7}$

b. Negara yang menggunakan sistem strong bicameralism

Semua negara menggunakan navette (shuttle) system, yaitu bahwa kamar yang mengusulkan RUU memberikan pada kamar yang lain RUU tersebut untuk dibahas, dan kemudian kamar tersebut memberikan pertimbangannya tentang RUU tersebut kepada kamr yang mengusulkan. ${ }^{8}$

c. Negara yang menggunakan sistem weak bicameralism

Pada berbagai negara tersebut, kewenangan pembentukan UU sangat tidak setara.Pemutus terakhir jika terdapat perbedaan diantara kedua kamar adalah berdasarkan mekanisme one chamber decision. ${ }^{9}$

d. Negara yang menggunakan sistem very weak bicameralism

Dari berbagai negara yang kedua kamarnya, memiliki kewenangan membentuk UU, baik yang menggunakan perfect bicameralism, strong bicameralism maupun weak bicameralism, tidak terdapat satu pola yang baku. Hanya terdapat beberapa pola yang umum dalam hal hubungan antarkamar dalam pembentukan UU, yaitu sebagian besar negara yang menggunakan sistem bicameral, mengatur bahwa 
dalam pembahasan RUU, baik finansial maupun non finansial, kedua kamar ikut serta dalam pembahasan. Selain itu persamaan lainnya adalah bahwa pada sebagaian besar negara tersebut UUDnya mengatur bahwa dalam hal RUU finansial, kewenangan untuk mengusulkan dan memutuskan jika terjadi perbedaan antarkamar, terletak pada kamar pertama. ${ }^{10}$

\section{Bentuk Bikameral di Negara} Amerika Serikat, Inggris, dan Perancis

\section{a. Amerika Serikat}

Amerika Serikat merupakan negara republik yang berbentuk federal dengan sistem pemerintahan presidensiil dengan corak utamanya ialah seorang Presiden menjadi kepala negara dan kepala pemerintahan yang dipilih melalui pemilihan yang dilakukan empat tahun sekali. Komposisi Parlemen negara Amerika Serikat disebutkan di dalam Pasal 1 ayat (1) Konstitusi Amerika Serikat yang berbunyi "All legislative powers here in granted shall be vested in a congress of United States, which shall consist of a Senate and
House of Representatives." (seluruh kekuasaan legislatif yang diberikan oleh UUD ditanamkan dalam sebuah Kongres Amerika Serikat yang terdiri dari sebuah Senat dan sebuah House of Representative.

Menurut Arend Lipjhart yang dikutip oleh Reni Dwi Purnowati $^{11}$, Amerika Serikat dikatagorikan sebagai strong becameralism, karenamemiliki symmetrical chamber dengan kekuasaan yang diberikan konstitusi sama dengan kamar pertama, memiliki legitimasi demokratis karena dipilih secara langsung dan juga incongruent karena berbeda dalam posisinya yaitu House yaitu sebagai perwakilan politik sedangkan Senate sebagai perwakilan negara bagian.

Pandangan dari Arend Lipjhart bukan tanpa alasan.Hal ini dapat analisis melalui hubungan kekuasaan yang terjalin antara Senat dan House yang mana berkedudukan sebagai badan legislasi dan majelis perwakilan yang terpisah secara

\footnotetext{
${ }^{11}$ Reni Dwi Purnowati, Implementasi Sistem Bikameral dalam Parlemen Indonesia, Rajawali Pers, Jakarta, 2006, Hlm. 55.
} 
jelas, tetapi juga memiliki hubungan yang sangat dekat. Berdasarkan pembagian tanggungjawab yang diatur oleh Konstitusi Amerika Serikat, setiap dewan memiliki kekuasaan untuk mengajukan RUU untuk setiap hal, namun dalam hal tertentu, diberikan wewenang khusus pada masing-masing kamar. Wewenang khusus tersebut antara lain :

1) House of Representative

a) Memulai mengeluarkan RUU mengenai Pajak;

b) Memiliki kekuasaan untuk melakukan impeachmentterhadap opejabat-pejabat federal dengan persetujuan Senat

c) Milih Presiden jika elektoral college gagal melalukannya. ${ }^{12}$

\footnotetext{
${ }^{12}$ Catatan: electoral college terkait dengan proses pemilihan Presiden di negara Amerika Serikat memang cukup unik. Meski dikatakan rakyat diberikan kesempatan untuk memilih Presiden dan Wakil Presiden secara langsun, namun suara mereka hanya berpengaruh hingga pada tingkat negara bagian, yakni pada penentu siapa calon yang memenangkan suara electoral (electoral vote) di negara bagian bersangkutan. Artinya memenangkan suara rakyat (poupular vote) secara nasional belum tentu memenangkan pertarungan karena yang menentukan adalah beberapa banyak suara electoral yang dikantunginya. Jadi, pada saat mencoblos rakyat bukan memilih langsung Presiden dan Wakil Presiden.Suara elektoral berbeda pada setiap negara bagian, tergantung besarnya jumlah wakil mereka di House, yang ditentukan jumlah
}

2) Senate Se $^{13}$

a) Merupakan kekuasaan satu-satunya untuk mencoba semua impeachment. Ketika dalam keadaan ini, merak harus disumpah atau dengan

penguatan/affirmasi.

Ketika Presiden AS diadili, yang mengetuai pengadilan tersebut adalah Ketua MA, dan tidak ada seorang pun yang dapat dihukum tanpa persetyjuan 2/3 dari anggota yang hadir;

b) Harus memberi prsetujuan (dengan suara setuju 2/3 dari seluruh suara) kepada setiap perjanjian yang diadakan oleh AS, sebelum perjanjian itu dapat berlaku;

c) Mempunyai hak untuk menyetujui atau tidak pengangkatan duta-duta besar, para menteri kabinet

penduduk di negara bagian yang bersangkutan.Jumlah tersebut kemudian ditambah dua untuk masing-masing negara bagian sebagai pencerminan 2 kursi setiap negara bagian di Senat.

13 Amir Makmur dan Reni Dwi Purnowati, Lembaga Perwakilan Rakyat, Pusat Studi Hukum Tata Negara Fakultas Hukum UI, Jakarta, 2005, Hlm 39 
dan konsul, hakim MA dll

pegawai USA yang masih

akan ditetapkan dengan

UU;

d) Semua RUU untuk menerbitkan pajak harus dimulai dari House, tetapi Senat mungkin mengusulkan atau setuju dengan amandemen seperti RUU yang lain.

Prosedur dalam pembutan UU oleh house merupakan kelemahan yang dimiliki lembaga tersebut. Misalnya prosentase suara yang diperlukan senat untuk membawa sebuah RUU ketingkat yang lebih tinggi, lebih banyak bila dibandingkaan dengan yang diperlukan house. Perbedaan jumlah keanggotaan dari kedua dewan tersebut juga memperangaruhi adanya peraturan yang berbeda. Karena house memiliki lebih banyak anggota, maka aturan mainnya lebih ketat dan lebih mengutamakan partai mayoritas dalam hal legislasi. Karena partai mayoritas dalam house menguasai prosedur, maka house juga menguasai hasil pemungutan suara dalam pembahasan berbagai isu dan legislasi. Bila partai mayoritas bisa menggalang suara yang bulat dari anggotanya untuk sebuah isu, kelompok oposisi atau minoritas pada dasarnya hanya memiliki sedikit pengaruh.

Dipihak lain, setiap anggota senat dari partai mayoritas maupun minoritas, memiliki kekuasaan individual dan tidak terkotak-kotak maupun minoritas dalam proses legislasi. Mereka bisa mendebaat panjang lebar dan mengusulkan amandemen untuk setiap RUU yang sedang dibahas. Untuk membuat pembagian kekuasaan legislasi menjadi lebih baik, prosedur didalam house berpihak pada mayoritas-sehingga keinginan rakyat bisaa berjalan tanpa ganjalan dari minoritassementara prosedur didalam senaat memberikan keuntungan kepada minoritas sehingga mereka bisa menghentikan mayoritas untuk bertindak terlalu cepat.namun house memiliki cara khusus untuk mempercepat pembuatan UU termasuk lewat media suara elektronik. Biasanya aturan-aturan dapat ditunda/ditangguhkan oleh 2/3 suara, atau tindakan yang segera dapat diambil oleh persetujuan 
sebagian besar para anggota

persidangan. Dengan rapat gabungan komisi house dapat menjalankan persidangan secara formal dan lebih cepat dari pada mengikuti aturan-aturan baku yang sudah ada, dan proses pengambilan suara bisa lebih cepat dan sederhana.

\section{b. Argentina}

Parlemen Argentina dikenal sebagai konres atau Congreso Nacional dengan model bentuk dua kamar (bikameral) dimana terdiri dari Senat atau Senado dan Dewan Perwakilan atau Cámara de Diputadosi. ${ }^{14}$ Congreso Nacional yang terdiri dari 2 kamar memiliki kewenangan formal antara lain:

1) Dalam hal yang berkaitan dengan teknis internal kedua kamar, seperti penentuan jadwal sidang, dan lain-lain. (Section 63-67 Konstitusi Argentina)

2) Setiap kamar dapat memanggil para menteri untuk menerima penjelasan atau laporan yang dianggap perlu. (Section 71 Konstitus Argentina)

\footnotetext{
${ }^{14}$ http://id.wikipeida.org/wiki/Argentina, diakses tanggal 3 Mei 2017
}

3) Melakukan kontrol eksternal. (Section 85 ayat (1) Konstitusi Argentina "The Legislative power is exclusively empowered to ecercise the external control of the national civil service as regard its estates and its economic financial and operative aspect."

Dalam pembentukan UU, chapter V section 77 Konstitusi Argentinamenegaskan bahwa RUU dapat diusulkan oleh anggota Congreso Nacional dan oleh kekuasaan eksekutif. Bila mana sebuah RUU telah disetujui oleh kamar dari mana RUU itu berasal, kemudian dikirim ke kamar lainnya untuk dibahas. Apabila sudah disetujui kedua kamar, RUU dikirim ke pemegang kekuasaan eksekutif untuk pemerikasaan (examination) guna mendapatkan persetujuan, dan jika disetujui maka RUU akan menjadi UU. ${ }^{15}$

\footnotetext{
${ }^{15}$ Section 78 Konstitusi Argentina yang menyatakan "when a bill is passed by the house in whcih it priginated, it is sent to the other house for its debate, once Approved by both, it is sent to the executive power of the nation for its examination; if it is also approvedm ut shall become law"
} 
Mengenai kewenangan formal masing-masing kamar dalam Congreso Nacional Negara Argentina antara lain :

1) Dewan Perwakilan atau Cámara de Diputadosi

a) Kedua kamar dalam Congreso Nacional dapat mengajukan RUU, akan tetapi khusus RUU tentang peningkatan pajak dan rekrutmen pasukan harus diajukan oleh Dewan Perwakilan atau Cámara de Diputadosi;

b) Memakzulkan Presiden, Wakil Presiden, Ketua dari Kabinet (Chief of the Ministerial Cabinet), MenteriMenteri, dan hakim Agung dalam hal pejabat tersebut melakukan perbuatan yang tidak patut (misconduct) atau kejahatan yang berkaitan dengan kewenangannya (crime committed in the fulfillment of their duties), atau kejahatan biasa (ordinary crimes).
2) Senat atau Senado

a) Mengajukan RUU

b) Berwenang bertindak sebagai hakim (judge) dalam hal pemakzulan yang dilakukan oleh Dewan Perwakilan atau Cámara de Diputadosi, dan jika yang dimakzulkan adalah Presiden maka harus dipimpin oleh Ketua MA dimana putusan diambil jika disetujui oleh 2/3 anggota.

c) Dalam hal adanya penyerangan terhadap negara, Senat atau Senado berwenang memberikan kuasa pada Presiden untuk mengumumkan adanya pengepungan (siege) atau tindakan-tindakan lainnya.

d) Senat atau Senado memberikan persetujuan terhadap penunjukkan dan dipindahkannya duta besar dan kementrian tertentu oleh Presiden.

e) Wakil Presiden juga merupakan Ketua Senat 
atau Senado, tapi tidak

memiliki hak suara

kecuali jika terjadi

keadaan dimana suara

berimbang. Jika Wapres

berhalangan atau harus

menggantukan Presiden

karena berhalangan

tetap, maka Senat harus

memilih Ketua

sementara.

Bentuk kamar pada parlemen

Negara Argentina mengarah

pada strong bicameralism.Hal

ini terlihat dengan

digunakannya one chamber

decision system, dengan

variasi yakni penentu adalah

kamar yang mengusulkan.

\section{c. Inggris}

Struktur Parlement Inggris, gabungan kedua kamar disebut Parliament, terdiri dari dua Majelis antara lain Majelis Rendah/Lower House (House of Common) dan Majelis Tinggi/Upper House (House of Lord). Keanggotaan kedua Majelis tersebut berbeda-beda, anggota Majelis Tinggi diangkat berdasarkan keturunan dan Majelis Rendah dipilih melalui pemilihan yang demokratis.
Analisis mengenai bentuk Bikameral negara Inggris dapat diruntun berdasarkan kewenangan formal yang dimiliki masing-masing kamar antara lain: ${ }^{16}$

1) Kewenangan Formal House of Commons dan House of Lord

a) Membentuk joint committee untuk membahas perkembangan

European Community;

b) Secara umum UU disetujui oleh kedua kamar.

2) House of Common

a) Memaksa pemerintah berhenti dengan mengeluarkan vote of no-confidence;

b) Meneliti pengeluaran negara, dalam kaitannya dengan RUU Keuangan (Finance Act);

c) Debat Joint Committee tentang usulan legislatif dari European Community dilakukan di House of Commons.

${ }^{16}$ Fatmawati, Truktur dan Fungsi...op.cit., Hlm 209. 
d) Sebagian besar menteri merupakan anggota House of Commons.

3) House of Lord
a) House of Lord berwenang menunda diundangkannya sebuah $\mathrm{UU}$;

b) Mengkritik dan meminta penjelasan dari pemerintah tentang kebijakan pemerintah;

c) Anggota House of Lord dapat diangkat menjadi menteri;

d) Menjadi pengadilan banding terakhir bagi semua kasus, baik pidana maupun perdata.

Mengenai bentuk Bikameral Inggris, dalam penelitian Arend Lipjhart Inggris dikatagorikan sebagai Bikameral antara medium-strenght bicameralism dan weak bicameralism. ${ }^{17}$ Namun jika dikaji lebih mendalam, model Bikameral Inggris menurut penulis lebih mengarah kepada asymmetrical bicameralism, karena kekuasaan yang dimiliki kamar kedua tidak sama dengan

${ }^{17}$ Efriza Syafuan Rozi, Parlemen Indonesia Geliat Volksraad Hingga DPD; Menembus Lorong Waktum Doeloe, Kini, dan Nanti, Alfabeta, Bandung, 2010, hlm 385 kamar pertama, komposisi keanggotaannya juga berbeda, dan ingcongruent karena berbeda dalam posisi kedua kamar tersebut, House of Common mewakili rakyat sedangkan House of Lord mewakili negara bagian.

\section{Bentuk Bikameral di Negara Indonesia dengan Kehadiran DPD}

Salah satu perubahan yang dilakukan terhadap UUd 1945 ialah dibentuknya badan baru yang bernama Dewan Perwakilan Daerah. Raison d'etre dari keberadaan DPD, untuk mengakomodasikan semangat check and balance tidak hanya antara pusat dan daerah, tetapi juga di dalam Parlemen itu sendiri. Namun, tidak adanya posisi equalmelainkan inequality (ketidaksetaraan) antara hubungan kejasamanya dengan Dewan Perwakilan Rakyat (DPR), serta posisi DPD yang timpang atau subordinated bukan coordinatedi dengan DPR dalam Undang-Undang Nomor 17 Tahun 2014 tentang MPR, DPR, DPD, dan DPRD banyak mereduksi kewenangan ideal yuang seharusnya dimiliki oleh DPD selaku kamar kedua dalam sebuah sistem bikameral. 
Berkaitan dengan RUU, memang pada dasarnya DPD memiliki kewenangan untuk mengajukan RUU dan juga ikut membahas RUU yang berkaitan dengan otonomi daerah, hubungan pusat dan daerah, pembentukan dan pemekaran serta penggabungan daerah, pengelolaan sumber daya alam dan sumber daya ekonomi lainnya, serta oerimbangan keuangan pusat dan daerah, seta yang berkaitan dengan perimbangan keuangan pusat dan daerah. Selain itu DPD juga memberikan pertimbangan kepada DPR attas RUU yang berkaitan dengan pajak, pendidikan, dan agama.

Akan tetapi, yang perlu digaris bawahi adalah imbas atau kekuatan dari kewenangan tersebut.Memang dalam bunyi UUD 1945 DPD memiliki kewenangan yang memiliki kaitan dengan aspek legislasi yang tercantum dalam Pasal 22D, namun kewenangan tersebut memiliki power yang sangatlah lemah.DPD hanya bergantung pada kekuatan legislasi DPR, dengan kata lain DPD seolah hanya sebagai aksesoris demokrasi dan mekanisme check and balance dalam kamar lembaga legislatif Indonesia.

Dari segi pengawasan, memang sebagai lembaga legislatif fungsi pengawasan adalah suatu keharusan yang dimiliki dan DPD memilikinya.Namun pengawasan itu sendiri bagiakan serigala tanpa taring dan dampak/impactnya sekali lagi ada di tangan DPR. Dalam Pasal 22D ayat (3) UUD 1945 disebutkan bahwa "DPD dapat melakukan pengawasan atas pelaksanaan UU mengenai; otonomi daerah, pembentukan, pemekaran, dan penggabungan daerah, hubungan pusat dan daerah, pengelolaan sumber daya alam da sumber daya ekonomi lainnya, pelaksanaan anggaran pendapatan dan belanja negara, pajak, pendidikan, dan agama serta menyampaikan hasil pengawasannya itu kepada DPD sebagai bahan pertimbangan untuk ditindak lanjuti”.

Kalimat terakhir dalam bunyi Pasal 22D ayat (3) UUD 1945 tersebut seungguh memangkas fungsi pengawasan DPD yang tanpa taring.Lagi-lagi hanya kepada DPR lah DPD bergantung.Segala upaya dan kinerja pengawasannya hanya sebagai bahan pertimbangan DPR untuk ditindak lanjuti tanpa adanya korelasi yang lebih baik antar keduanya. Bahan pertimbangan yang merupakan hasil pengawasan DPD oleh DPR memang dibahas untuk ditindaklanjuti, akan tetapi 
pembahasan tersebut tanpa dapat meminta penjelasan langsung terkait hasil pengawasan yang dilakukannya kepada pemerintah.

Jika dikaji berdasarkan latar belakang dibentuknya DPD, pada dasarnya merupakan lembaga perwakilan yang basis representasinya ialah daerah, sedangkan untuk DPR orientasinya dengan skala nasional.Sehingga ada perbedaan mendasar terkait keanggotaan DPR dan DPD.Memang mekanisme pemilihan anggotanya sama-sama dilakukan melalui pemilihan umum.Akan tetapi sistem yang digunakan dalam pemilihan umum keduanya berbeda.Untuk keanggotaan DPR, pemilihan umum secara langsung oleh rakyat melalui sisttem proporsional terbuka yang memang berguna dalam memperkuat kelembagaan partai politik yang bersifat nasional (political instittutional building). Sedangkan DPD anggotanya dipilih secara langsung oleh rakyat melalui sistem distrik murni, yaitu dengan cara memilih tokoh yang dikenal di daerah yang bersangkuan berdasarkan perhitungan "the winner take all". ${ }^{18}$

\footnotetext{
${ }^{18}$ Jimly Asshiddiqie, Format Kelembagaan Negara Dan Pergeseran Kekuasaan Dalam UUD 1945, FH UII Oress, Yogyakarta, 2005, Hlm 165
}

Yang menarik berkaitan dengan keanggotaan kedua kamar ini ialah sama-sama memiliki legitimasi yang kuat dari rakyat dengan orientasi yang berbeda dalam perwakilannya. Dan bahkan dengan menutup sistem kepartaian dalam pemilihan anggota DPD, justru membuat keanggotaan DPD memiliki legitimasi yang cenderung lebih kuat dari pada DPR.Tetapi hal ini berbanding terbalik jika dikaitkan dengan kewenangan yang sangat terbatas yang dimiliki oleh DPD. Menyinggung daripada perbedaan keanggotaan kedua kamar tersebut, kontruksi bentuk kamarnya lebih akan menembus kecenderungan pada bentuk bikameral yang unsurnya relatif atau agak berbeda (likely bicameralism). Pandangan ini tidak lepas bahwa keduanya merupakan unsur yang dipilih melalui pemilihan umum namun ada perbedaan representasi saja., namun koordinat keduanya memiliki legitimasi yang kuat dari rakyat.

Secara rasional dengan adanya pandangan yang inequal antara DPR sebagai kamar pertama dan DPD selaku kamar kedua dalam Legislatif Indonesia, jelas bahwa bentuk bikameral Indonesia adalah weak bicameralism bahkan mengarah 
kepada very weak becameralism. Pandangan ini tidak lepas dari kedudukan DPD dalam struktur dan fungsi legislasi dalam UUD 1945 yang sangat membatasi kewenangan DPD. DPD hanya berwenang mengusulkan dan membahas RUU tanpa memiliki votingright (hak menolak) dan juga tidak memiliki approval autority (kewenangan menyetejui). Sedangkan mengenai unsurnya, bentuk kamar dengan kehadiran DPD ini ialah dengan unsur yang relatif atau agak berbeda (likely bicameralism).

\section{PENUTUP}

\section{Kesimpulan}

a. Ada beberapa bentuk bikameral berdasarkan struktur parlemen dan fungsi legislasi yang lazim diterpakan di negara-negara dunia antara lain yakni sistem Perfect Bicameralism, Sistem Strong Bicameralism, Sistem Weak Bicameralism, Sistem Very Weak Bicameralism.

b. Berkaitan dengan negara Amerika Serikat, Amerika Serikat dikatagorikan sebagai strong becameralism, karenamemiliki symmetrical chamber dengan kekuasaan yang diberikan konstitusi sama dengan kamar pertama, memiliki legitimasi demokratis karena dipilih secara langsung dan juga incongruent karena berbeda dalam posisinya yaitu House yaitu sebagai perwakilan politik sedangkan Senate sebagai perwakilan negara bagian.Untuk negara Argentina, Bentuk kamar pada parlemen Negara Argentina mengarah pada strong bicameralism.Hal ini terlihat dengan digunakannya one chamber decision system, dengan variasi yakni penentu adalah kamar yang mengusulkan.Sedangkan untuk Inggris, dalam penelitian Arend Lipjhart Inggris dikatagorikan sebagai Bikameral antara mediumstrenght bicameralism dan weak bicameralism. Namun jika dikaji lebih mendalam, model Bikameral Inggris menurut penulis lebih mengarah kepada asymmetrical bicameralism, karena kekuasaan yang dimiliki kamar kedua tidak sama dengan kamar pertama, 
komposisi keanggotaannya juga berbeda, dan ingcongruent karena berbeda dalam posisi kedua kamar tersebut, House of Common mewakili rakyat sedangkan House of Lord mewakili negara bagian.

c. Dengan kehadiran DPD serta menelurusi kedudukan, kewenangan, serta fungsifungsi yang dimiliki lembaga DPD yang inequal dengan DPR. Secara rasional dengan adanya pandangan yang inequal antara DPR sebagai kamar pertama dan DPD selaku kamar kedua dalam Legislatif Indonesia tersebut, jelas bahwa bentuk bikameral Indonesia adalah weak bicameralism bahkan mengarah kepada very weak becameralism.Pandangan ini tidak lepas dari kedudukan DPD dalam struktur dan fungsi legislasi dalam UUD 1945 yang sangat membatasi kewenangan DPD. DPD hanya berwenang mengusulkan dan membahas RUU tanpa memiliki votingright (hak menolak) dan juga tidak memiliki approval autority (kewenangan

menyetejui). Sedangkan mengenai unsurnya, bentuk kamar dengan kehadiran DPD ini ialah dengan unsur yang relatif atau agak berbeda (likely bicameralism).

\section{Saran}

Sudah saatnya kelembagaan DPD ini diperkuat kedudukan dan fungsinya.Hal ini tidak lepas dari bentuk kamar di Indonesia yang sangat timpang antara DPR dan DPD. Dengan kata lain jika konsisten dengan mengalamatkan DPD sebagai lembaga legislatif, maka amandemen ke 5 UUD 1945 bukan hanya wacana saja, namun jika memang akan seperti ini, DPR akan condong kepada lembaga yang terlalu kuat, dan lembaga yang kuat cenderung korup sebagai mana pandangan Lord Action "power tend to corrupt".

\section{DAFTAR PUSTAKA}

Amir Makmur dan Reni Dwi Purnowati. 2005. Lembaga Perwakilan Rakyat. Pusat Studi Hukum Tata Negara Fakultas Hukum UI, Jakarta.

C.F Strong. 1975. Modern Polituical Constitution An Introduction to the Comparative Study of Their History 
and Existing Form. Sidwick \& Jackson Ltd, Londong.

Efriza Syafuan Rozi. 2010. Parlemen Indonesia Geliat Volksraad Hingga DPD; Menembus Lorong Waktum Doeloe, Kini, dan Nanti. Alfabeta, Bandung.

Fatmawati, 2010, Truktur dan Fungsi Legislasi Parlemen Dengan Sistem Multikameral; Studi Perbandingan Antara Indonesia dan Berbagai Negara, UI Press, Jakarta.

Hans Kelsen. General Theory of Law and State. Russel \& Russel, New York.

Jimly Asshiddiqie. 1996. Pergumulan Peran Parlemen dan Parlemen dalam Sejarah; Telaah Perbandingan Konstitusi Berbagai Negara. UI Press. Jakarta.

1

Jimly Asshiddiqie. 2005. Format Kelembagaan Negara dan Pergeseran Kekuasaan Dalam UUD 1945. FH UII Press, Yogyakarta.

Reni Dwi Purnowati. 2006. Implementasi Sistem Bikameral dalam Parlemen Indonesia. Rajawali Pers, Jakarta.

Saldi Isra. 2010. Pergeseran Fungsi Legislasi; menguatnya Model Legislasi Parlementer dalam Sistem Presidensial Indonesia. Rajawali Pers, Jakarta.

Undang-Undang Dasar Negara Republik Indonesia Tahun 1945

Konstitusi Negara Amerika Serikat.

Konstitusi Negara Argentina.

Konstitusi Negara Inggris. 